\begin{tabular}{ccc}
\hline Bentham open & The Open Automation and Control \\
SrossMark & Systems Journal \\
Content list available at: www.benthamopen.com/TOAUTOCJ/ & DOI: $10.2174 / 1874444301608010005$ \\
\hline
\end{tabular}

\title{
Retraction Notice: Seismic Signal Analysis and System Development Based on Wavelet Analysis
}

F. Yongkai* and W. Chunhai

Department of Computer Science and Technology, China University of Petroleum, Beijing, China

\section{RETRACTION}

The Publisher and Editor have retracted this article [1] in accordance with good ethical practices. After a thorough investigations we believe that the peer review process was compromised. The article was published on-line on 26-06-2015.

\section{REFERENCE}

[1] Yongkai F, Chunhai W. Seismic signal analysis and system development based on wavelet analysis. Open Autom Control Syst J 2015; 7 : $502-9$.

\section{(C) Yongkai and Chunhai; Licensee Bentham Open.}

This is an open access article licensed under the terms of the Creative Commons Attribution-Non-Commercial 4.0 International Public License (CC BY-NC 4.0) (https://creativecommons.org/licenses/by-nc/4.0/legalcode), which permits unrestricted, non-commercial use, distribution and reproduction in any medium, provided the work is properly cited.

\footnotetext{
* Address correspondence to this author at the Department of Computer Science and Technology, China University of Petroleum, Beijing, China;
} Tel:010-89733797; E-mail: fanyongkai@cup.edu.cn 